\title{
Henry Bauchau : Diotime et les lions. A translation experience
}

Henry Bauchau's works are not readily accessible in the USA. English translations of some of his Oedipus and Antigone novels are included in academic libraries' collections, such as those of the U.C. library system. Bookstores specializing in foreign literatures may carry a few titles as well, such as the European Book Company in San Francisco, where I found a French copy of the second edition of Diotime. This is hardly surprising since, according to a March 2004 article in Le Monde Diplomatique, in the US, only $2.8 \%$ of all publishing is in translation, of which only $0.8 \%$ is from the French language ${ }^{\mathbf{2 1 0}}$.

Like many Belgian authors faced with the predicament of being born in "a country of no language" ("du pays de la non-langue"211), Bauchau went to live in Paris and was drawn to psychoanalysis and the Lacanian discourse, trying to go beyond history, beyond birth and naming, to rediscover some elemental story. One could interpret Diotime's story as one gesture in that process. There is nothing of Belgium there, except perhaps the easy union of the prosaic and the fantastic, and a blind and stubborn inner strength that drives its characters to find out what they are meant to be.

The story of Diotime et les lions appeared tangentially in Bauchau's consciousness, as he explains in his writing journals Jour après Jour. Journal d'Edipe sur la route (1983-1989) and Passage de la Bonne-Graine. Journal 1997-2001. Like his other characters, Diotime surfaced as he was "listening" to a story telling itself to him through the writing process. Diotime et les lions was published as a long story or short novel in 1991, a year after the long novel it branched from. It resonated deeply with French readers and has since been adapted for the theatre and the opera. No English translation of it has been published so far. My own translation resides in the library collection of Sonoma State University, where it was presented as a M.A. English thesis, with an analytical commentary in June 2004.

210 Pierre Lepape, "La Dictature de la 'world literature': hyperconcentration chez les éditeurs", dans Le Monde Diplomatique, Mars 2004, p. 24.

211 Marc Quaghebeur, "Balises pour l'histoire de nos lettres", dans Alphabet des Lettres Belges de Langue Françaises, Bruxelles, Association pour la Promotion des Lettres Belges de Langue Française, 1982, p. 198. 


\section{Style and contents}

Diotime et les lions is a coming-of-age story that unifies the familiar rites of passage of both genders. Diotime is taught homemaking skills by her mother within the security of the family compound. Like most young women, she is confused by the appearance of love in her life, goes through a process of fear, jealousy, assent, refusal, impatience and sorrow, before she enters the state of "true love". But unlike most traditional princesses, she also learns to confront wilderness and overcome fear, she is allowed to kill and to be blessed by spilled blood, she learns to sing and dance among men who desire but respect her.

Diotime combines the feminine blood cycle of fertility with the masculine blood shedding of war and survival. She embodies a new myth of self-completion and gender reconciliation. As passionate as Antigone, Diotime does not share the tragic stance and fate of Sophocles's heroin, alone and pitted against the world. Her path leads to happiness in serene acceptance of time passing and the necessity of death. She reconciles love of her blood relatives with the foreignness of sexual love, love of the artful spring in her mother's garden with the wild passion of fire, love of lost childhood with impending old age.

Thus this story, grown out of the imagination of an 83-year old European man, resonates like an old myth, transcending culture and gender. Like all mythical characters, Diotime, Cambyse, Kyros, Arsès, and the Old-Child, have a godlike dimension, though they are possessed of very human emotions and we have no trouble projecting our emotions into them. But where and when they lived doesn't matter. While we see them vividly as individuals, they also represent universal states of being.

On February 14th, 1995, Bauchau writes and I translate: "ii]t is true that I tend to enlarge my characters, [...] my vision tends more toward the epic. It is a natural movement for me"212. On April 2nd, 1999, asked about his use of Greek myths by a group of high school students, he says: "[y]ou see, I do not separate reality from the real imaginary. I believe deeply that the dream is a form of reality. Myths represent something of today's reality. [...] Why not make use of them?"213.

Several times in his journals and conversations Bauchau alludes to the struggle between Dionysus and Apollo, which writing painfully reconciles. The plot of Diotime places the characters in a new enactment of the eternal conflict between "animality" and spirituality. Wild beasts are our ancestors. Wisdom sits on the back of a wandering buffalo. Passion cries out but knowledge does not need to speak.

$212 J A$, p. 382.

213 Athénée Royal J. Bara, Tournai. 
The mirror in the garden shows the young woman that she does not need to give up one for the other. The Greek vision of order marries Persia's ancient fierceness. Respect for nature and history are combined in a culture where woman's voice is as strong as man's. It is a satisfying, cathartic story, especially for contemporary readers haunted by their differences and the world's irreconcilable conflicts.

In an age when literary critics and theorists look for multiple discourses, underlying assumptions, contradictions, parody, there is little here to deconstruct. The point of view may be feminist but masculinity is represented in its traditional form. The main characters seem to belong to a social elite but no one seeks to take over their position. The field is free of social, political or religious agendas and claims. The story rather resembles a fable; it has a moral agenda: the education of the soul. But the very goal it seeks to reveal is not one that can be taught. Only one process of attaining it can be shown. Luminous, it stands as an invitation, not a prescription.

On October 23rd, 1991, Bauchau records a passage of a letter from one of his readers: "[i]t is not as a surprise that this text is effective but rather as a slow clearing for the language... You seem to tell such simple things but under the words another discourse proceeds, that one has to take time to assimilate into one's own"214. The theme of "the road" is essential for Bauchau. If Pierre-Jean Jouve was correct in his view that the poet basically spends his life repeating one word, for Bauchau, that unique word is "the road, which goes toward initiation" ${ }^{215}$. On December 3rd, 1992, he remarks about his novel Edipe sur la route: "I walked this novel as much as I wrote it... The road is a way of life"216.

Walking also releases our everyday hold on time. Diotime et les lions is divided in two parts. The first and longer one tells the story of specific events happening on certain days. The second part, though much shorter, slows us down and blurs the days' edges. Indian time is limitless. In it the story grows like a plant. "And plants live in a different form of time"217. The year 1994 was marked for Bauchau by his wife's gradual loss of memory, "accompanied by a very slow, but very real walk toward release and toward the smile"218. It was as if when he wrote Diotime, the author's unconscious was anticipating the path he would be led to some years later.

$214 J A$, p. 122.

215 Ibid., p. 363.

216 Ibid., p. 195.

217 Ibid., p. 301.

218 Ibid., p. 369. 


\section{Problems of translation}

Bauchau's story is told directly by the story's heroine. There is no apparent intermediary between her voice and our ear. It is as if we were sitting by the fire with Oedipus and Antigone, listening to Diotime's tale of her childhood. She brings forth her memories. The author, like us, listens to the voice of a fourteen-year old girl. Impetuous, she throws herself into action, then painfully learns to slow down. Her emotions are clear and call for our sympathy, without any need for inner dialogue, editorial insights, philosophical digressions. The story is told like an epic, an adventure. It ends on a clear resolution, without commentary.

The translator might be initially relieved by the text's transparency. This text has a clear beginning and an end; a logical sequence of events; no jargon, doubleentente, no irony, no self-reflexivity. The voice is poetic, consistent, focused on the things themselves; no distancing. It is just a matter of finding the correspondent word for everything. And the language is plain, not esoteric.

But the very transparency of the original text may be a problem. Under the clear surface, many pitfalls lurk. For how does one find the exact corresponding word for everything? To quote Walter Benjamin from The Task of the Translator: "[t]he words 'Brot' and 'pain' 'intend' the same object, but the modes of this intention are not the same. It is owing to these modes that the word 'Brot' means something different to a German than the word 'pain' to a Frenchman, that these words are not interchangeable for them"219.

Perhaps because I have lived an equal amount of time in the two languages I am working with, I have gained some privileged grasp of both "modes of intention", but I am still translating from my mother tongue into my second language, so that for me, the primal image of the "horse", for instance, is that of the heavy "cheval brabançon" which used to pull barges along the Belgian canals, like the working pair featured in the etching my father hung above his desk, while I now see "horse" as a light and free creature running over golden hills "out here" in the West.

Bauchau's horses, always associated with a male rider, may be closer to the reflection he notes in his journal of January 6th, 1992, about an exhibit of Gericault's paintings he just saw. "What struck me the most? First of all, the almost continuous presence of horses. Their beauty, their strength, their impetuosity. Instinct in all its power, the impulse, contained rather than mastered by man who gains glory from it"220. On July 8th, Bauchau remembers that Blanche Jouve pointed out to him that horses "were everywhere in his novel Le Régiment noir"221.

219 Walter Benjamin, "The Task of the Translator", dans Hannah Arendt (ed.), Illuminations: Essays and Reflections, translation by Harry Zohn, New York, Schocken Books, 1968, p. 74.

220 JA, p. 135.

$221 J A$, p. 161. 
The "lion" I know is the African beast I first saw in the Museum of the Congo, a Pygmy man with a spear standing next to him for size, on an elementary school fieldtrip to Tervueren, near Brussels. But Diotime's lion is the Leo Persicus, smaller and thinner, closer to a tiger. He was hunted to extinction by ancien kings and noblemen in Greece, Egypt, Mesopotamia, Persia. There is but a small band of his species alive today in Western India's Gujarat preservation ${ }^{\mathbf{2 2 2}}$. His small roaming grounds are half way from Greece and China, between which Bauchau's text seems to arch a bridge.

Because I studied Greek but no Chinese, I stand closer to the first and must follow Diotime's journey to reach the second. Bauchau also lives in the Western tradition but some of his earlier works attest to his interest in the East, which he has studied much more deeply than I have. On October 16th, 1990, he notes in his journal: "[n]o doubt there is in me, through Diotime and Lao-Tseu, a certain link between Greece and China"223. Will my translation lose this underground meandering?

If there are such discrepancies of experience attached to apparently equal and transparent words, what can one say of the words and expressions which do not have an equivalent in the second language? In the very first paragraph of the story, I hit against the familiar notion of "chez nous" and puzzled over it for a long time. Where is Cambyse arriving? Literally "at ours"; do I render that by "our house", the "compound", or the "homestead"? I chose "our place", as the closest approximation to the intimacy suggested by the French expression, which nonetheless means more than the house, but includes the grounds, the total environment that is ours, in which we find ourselves at home. In the next sentence, the same problem arises with "chez lui" and this time, "at home" seemed the better choice, with its connotations of being at ease, in control of the situation.

The first sentence offers an example of another difference between the two languages: English has a way of condensing things that allows it to express with few words what French says with many more. "Arriver au galop" (literally "arriving on his galloping horse") can be expressed with one verb "galloped into". The English verb, in its conjugated form, renders the action with more dynamism, combining the components of arriving and galloping, in one swift gesture. Later in the novella, the gradual transformation of the Old One into the Elder Child faces the translator with another challenge. The compounded words are making creative use of the French language to begin with; to convey their transformation of meaning smoothly, without awkwardness, is not easy.

During one of our conversations about my work, my thesis advisor, Noelle Oxenhandler, Sonoma State University's Professor of English, pointed to the

222 David Quammen, Monster of God: the Man-eating Predator in the Jungles of History and the Mind, New York, Norton, 2003, p. 37.

$223 J A$, p. 66. 
richness of the English language, compared to French's smaller lexicon and greater clarity. English casualness about "purity of language" and the complex history of its linguistic development and use, has allowed it to incorporate several vastly different vocabularies: Greek, Latinate, Germanic, Anglo-Saxon. Therefore it offers a multiplicity of word choices, in both sound and meaning.

French has stood its ground and fiercely defended its integrity. Until recently at least, when English started to creep in as its status of world language was confirmed, French has been faithful to its Latin and Greek ancestry. As a result, its vocabulary is less extensive but necessarily more chiseled or more precise. There is also a greater harmony of sounds, all belonging to the same lexical family, which in turn gives the impression of a greater harmony between sound and form (unless that is my assumption because it is my primary language and I originally associated objects and concepts with French words). William Trask, translator of French and German, adds another dimension, that of the rational, Cartesian mind when he mentions that French appeals to his "eighteenth-century logical-minded" self... "to which German is antithetical"224.

These may be the reasons why French appears to be clearer, more transparent, more formal, while English expresses exuberance, a messier and more casual form of experience. In view of that comparison, the particular text I am translating challenges me to find in the English language, the corresponding simplicity and formality of the French. The challenge is mitigated by the fact that Bauchau's language is prosaic in his choice of words, though poetic in his form. It is hard to find in Diotime et les lions words that are not used in everyday French conversation. The translator may hesitate to choose among several English equivalents, but at least she can allow English to maintain its immediacy, without having to harness it into more abstract constructs.

The very first words of the text: "dans mes plus lointains souvenirs" were the site of a long debate within myself. "Souvenir" could become "memory" or "remembrance" but the latter seemed too formal. "Lointain" could become many words: "far away", "distant", "earliest", "remote" or "ancient". In the end, I chose the spatial "remote" over the temporal "earliest" or "ancient" because "lointain" evokes the horizon of a landscape, the limit between earth and sky, a stretching of the eye as far as one can see. Diotime's childhood memory is the most remote from the other pole of her story; it is all tension and expectation, hers and Cambyse's, fierce on his galloping horse, while the end finds Diotime at peace after Cambyse falls from his horse and dies, reconciled with his life and losses. From her remote child's standpoint, Diotime departs on her way to womanhood and wisdom.

224 Edwin Honig, The Poet's Other Voice. Conversations on Literary Translation, Amherst, University of Massachusetts Press, 1985, p. 17. 
I notice that I used the word "become" to designate the transfer process from French word to English. This becoming is indeed a "trans-fert", a "trans-mission" of one value to another, such as Denise Levertov describes in her wonderful 1973 essay, "Great Possessions", where she views "the artist as translator"225, after Proust who believed that we must all "translate that essential book that already exists in each of us"226. The latin "transferre" means "to carry across", "to ferry to the far shore". Like the poet or doubly so, the translator must carry or convey the reader to the other shore "not in the sense of bringing the information to the receiver but of putting the receiver in the place of the event - alive"227. In the transmitting operation, we are both at the "sending" and the "receiving end", seeing things new as we individually attach our own private mythologies to the story in front of us. This viewpoint allows us to step outside of the old conundrum of faithfulness versus license that translators can't help engage in, when questioned about their craft, swinging one way or the other, according to their experience, their skill and mostly their temperament.

To say that a word "becomes" another word in another language is also to acknowledge the transformation operated on the language itself, not just on the story's "modes of intention" or the reader's vision of his own experience. In his conversation with William Honig, William Trask may be advocating the opposite of transparency when he brings up Ortega y Gasset's notion that translation should give the experience of the language from which the translation is made, so that for instance it sounds like Latin with English words. And "the way you can do it is to have your English be so English in the passages that don't matter that you can get away, where it does matter, with something foreign" ${ }^{\text {228 }}$. This notion is entirely different from that of the translator's license to rework the original text according to his own temperament. Ben Bellitt, for example, is of the opinion that "the immediate aim of translation is pleasure not truth"229. I find Trask's position more interesting as an invitation to stretch a language's limits and give it new possibilities.

Walter Benjamin was on a similar track when he wrote in his introduction to his translation of Baudelaire's Tableaux Parisiens, published in 1923 : "[i]t is the task of the translator to release in his own language that pure language which is under the spell of another, to liberate the language imprisoned in a work in his re-creation of that work"230.

225 Denise Levertov, "Great possessions", dans The Poet in the world, New York, New Directions, 1973, p. 93 .

226 Marcel Proust, Le Temps Retrouvé, cité dans Gabrielle Townsend, Proust's Imaginary Museum. Reproductions and Reproduction in À la recherche du temps perdu, Berne, Peter Lang, 2008, p. 190.

227 Denise Levertov, "Great possessions", art. cit., p. 94.

228 Edwin Honig, The Poet's Other Voice [...], op. cit., p. 18.

229 Ibid., p. 59.

230 Walter Benjamin, "The Task of the Translator", art. cit., p. 80. 


\section{Conclusion}

The last statement alludes to the Babelian dream of one true silent language in which all diverse languages converge. Translation apprehends and facilitates the convergence, though it remains a virtual effort. Did I manage to release in English that "pure language" which our unconscious apprehends under the surface of the French? Did I preserve the mystery?

Bauchau himself wonders about translation after attending a colloquium on translation in London on October 26th, 1994 :

In translation, one rediscovers the mystery of reading. The author lays down a track, but the true reader reads his own book, adding to the author's words her own experiences, meditations and sensations. The good translator does this also, but as her readings and her work proceeds, she moves closer and closer toward the author. ${ }^{231}$

Looking back on this particular translating experience, I would agree with that assessment. While my initial perception and enjoyment of the story have not paled, subsequent readings and exploration of themes and language have deepened them. To the extent that people are able to communicate their psychic life, my own has been traversed by strong elements of Bauchau's imaginaire. The reactions of my translation's readers seem to indicate that they have been moved by the story in similar ways. That is the best I could hope for.

I will not claim to have come to adopt any particularly theory about the translation process, though my choice of citations reveals my preferences. I still see translation as an empirical move, open to many possibilities. But I also see it as a wonderful opportunity to enter the difference between languages, perceptions, significations. In our multicultural, post-colonial age of homelessness, displacement, disenchantment, translation is a privileged tool and means to relate, to reconnect and to re-enchant what we may have lost or did not know we could have access to.

Not only is it an exciting literary experience but it also has social importance. If Babel's multiplication of languages was the divisive curse imposed on humanity by a threatened god, surely translation offers a healing path toward renewed understanding between individuals and between peoples.

Godelieve Uyttenhove

Sonoma State University

$231 J A$, p. 363. 